\title{
Physiological response of Solanum nigrum to salt stress
}

\author{
Renyan Liao*, Lan Zhang \\ Ya'an Polytechnic College, Ya'an, Sichuan 625000, China
}

\begin{abstract}
The effects of salt stress $(100,200,300 \mathrm{mmol} / \mathrm{L})$ on physiological characteristics of Solanum nigrum seedlings were studied by pot experiment. The results showed that the contents of chlorophyll a, chlorophyll b, carotenoids and total chlorophyll in S. nigrum leaves showed a trend of first flattening and then increasing with the aggravation of salt stress. With the aggravation of salt stress, the net photosynthetic rate, stomatal conductance and intercellular $\mathrm{CO} 2$ concentration of $S$. nigrum decreased gradually, and reached the lowest value when the $\mathrm{NaCl}$ concentration was $300 \mathrm{mmol} / \mathrm{L}$. With the increase of $\mathrm{NaCl}$ concentration, the SOD activity of $S$. nigrum leaves decreased gradually. When the concentration of $\mathrm{NaCl}$ was $300 \mathrm{mmol} / \mathrm{L}$, the SOD activity of $S$. nigrum decreased by $53.39 \%(\mathrm{P}<0.05)$. The activities of POD, CAT and soluble protein in $S$. nigrum increased first and then decreased with the increase of $\mathrm{NaCl}$ concentration. When the concentration of $\mathrm{NaCl}$ was $100 \mathrm{mmol} / \mathrm{L}$, the activities of POD, CAT and the content of soluble protein reached the maximum.
\end{abstract}

\section{Introduction}

With the rapid development of economy, there are many environmental problems, among which soil salinization is one of them. Soil salinization is also a worldwide environmental problem, which is one of the main causes of land desertification and soil degradation [1]. According to statistics, the area of saline soil in China is about 520million ha, of which, the salt soil is about 240 million ha [2]. Saline alkali land is not only huge in area, but also widely distributed in northwest, north, northeast and coastal areas of China [3]. Salinization can reduce soil porosity, make soil easy to board and permeability becomes poor. It can also reduce the content of soil organic matter, and the degree of carbon and nitrogen mineralization can decrease, which can lead to the decline of soil fertility [4]. In short, salinization of soil will have a negative effect on plant growth and development. The results showed that the chlorophyll content of three turfgrasses increased firstly and then decreased with the aggravation of salt stress [5]. Pn, Gs and $\operatorname{Tr}$ of the three blueberry seedlings decreased gradually with the increase of $\mathrm{NaCl}$ concentration, while intercellular $\mathrm{CO}_{2}$ concentration increased gradually [6]. In addition, salt stress also causes the plant anti reverse reaction, and by improving the activity of antioxidant enzymes, it can resist the damage of reactive oxygen on cells [7]. The results showed that superoxide dismutase (SOD), peroxidase (POD), and catalase (CAT) activities in tomato leaves increased with the increase of $\mathrm{NaCl}$ concentration [8].

Solanum nigrum is a plant of Solanaceae, which is distributed all over China. It grows on the edge of fields, roadsides, hillsides and grasslands [9]. As a Chinese herbal medicine, $S$. nigrum has many effects such as clearing away heat and detoxification, antiphlogistic and diuretic. In recent years, studies have found that $S$. nigrum also plays an important role in anti-cancer, and the alkaloids contained in its extract are a variety of effective anti-tumor components, which has attracted extensive attention of scholars at home and abroad [10]. Therefore, S. nigrum has important research value. In this experiment, $S$. nigrum was used as material to study the effect of salt stress on the physiological characteristics of $S$. nigrum seedlings by irrigating different concentrations of $\mathrm{NaCl}$ solution.

\section{Materials and method}

\subsection{Materials}

The S. nigrum seeds used in the experiment were collected from the farmland around the Yucheng District, Ya'an City, Sichuan Province, China.

\subsection{Experimental design}

In September 2020, S. nigrum was seeded in a 32-hole tray. Mix perlite, coconut brick and soil in the ratio of 1:1:1 and put them into $8 \mathrm{~cm} \times 10 \mathrm{~cm}$ (height $\times$ diameter) plastic basin for use. When the seedlings grew to $3-4 \mathrm{~cm}$, the seedlings were transplanted into plastic pots with 3 plants in each basin. After that, the plastic pot was placed in a large tray and cultured with Hoagland nutrient solution. When the seedling grew to $15 \mathrm{~cm}(8$ true leaves were expanded), salt stress treatment was carried out. Four $\mathrm{NaCl}$ concentration gradients [0 (CK), 100, 200 and $300 \mathrm{mmol} / \mathrm{L}$ ] were set in the experiment, and each treatment was repeated 4 times. Prepare $1 \mathrm{~L} \mathrm{NaCl}$

*Corresponding author. E-mail: 51699474@qq.com 
solution and pour it into the large tray, and replace it every 2 days. After 7 days of culture, the leaves were collected for determination of related indexes.

Photosynthetic rate was measured by Li-6400 portable photosynthesis instrument. The photosynthesis parameters of the photosynthesis instrument are manually controlled with a $\mathrm{CO}_{2}$ concentration of 400 $\mu \mathrm{mol} / \mathrm{mol}$, a temperature of $30^{\circ} \mathrm{C}$, and a light intensity of $1000 \mu \mathrm{mol} / \mathrm{m}^{2} / \mathrm{s}$. The photosynthetic parameters include net photosynthetic rate $(\mathrm{Pn})$, transpiration rate $(\mathrm{Tr})$, stomatal conductance (Gs), and intercellular $\mathrm{CO}_{2}$ concentration $(\mathrm{Ci})$. The contents of photosynthetic pigments (chlorophyll a, chlorophyll b, total chlorophyll and carotenoid) in mature leaves of $S$. nigrum were measured. The activity of antioxidant enzymes (SOD, POD, and CAT) and the content of soluble protein in $S$. nigrum were measured [11].

\subsection{Statistical analyses}

Spss22.0 was used to analyze the data and Duncan's new complex range method was used for multiple comparisons (significance level was $5 \%$ ).

\section{Results and discussion}

\subsection{Effect of salt stress on the photosynthetic pigment content of $S$. nigrum}

Compared with the control, the contents of chlorophylla, carotenoid and total chlorophyll in S. nigrum leaves were significantly increased by 200 and $300 \mathrm{mmol} / \mathrm{L} \mathrm{NaCl}$ solution, and chlorophyll b content in $S$. nigrum leaves was significantly increased by $300 \mathrm{mmol} / \mathrm{L} \mathrm{NaCl}$ solution, but there was no significant difference between the treatment of $100 \mathrm{mmol} / \mathrm{L} \mathrm{NaCl}$ solution and the control.

Table 1. The photosynthetic pigment content of S. nigrum.

\begin{tabular}{|c|c|c|c|c|}
\hline $\begin{array}{c}\mathrm{NaCl} \\
(\mathrm{mmol} / \mathrm{L})\end{array}$ & $\begin{array}{l}\text { Chlorophyll } a \\
\text { (mg/g) }\end{array}$ & $\begin{array}{l}\text { Chlorophyll } b \\
\text { (mg/g) }\end{array}$ & $\begin{array}{l}\text { Carotenoid } \\
\qquad(\mathrm{mg} / \mathrm{g})\end{array}$ & $\begin{array}{c}\text { Total chlorophyll } \\
(\mathrm{mg} / \mathrm{g})\end{array}$ \\
\hline 0 & $0.703 \pm 0.004 b$ & $0.240 \pm 0.004 b$ & $0.126 \pm 0.002 b$ & $0.943 \pm 0.008 b$ \\
\hline 100 & $0.710 \pm 0.003 b$ & $0.243 \pm 0.005 \mathrm{ab}$ & $0.126 \pm 0.004 b$ & $0.953 \pm 0.008 b$ \\
\hline 200 & $0.774 \pm 0.025 \mathrm{a}$ & $0.255 \pm 0.005 \mathrm{ab}$ & $0.144 \pm 0.000 \mathrm{a}$ & $1.030 \pm 0.030 \mathrm{a}$ \\
\hline 300 & $0.773 \pm 0.011 \mathrm{a}$ & $0.262 \pm 0.011 \mathrm{a}$ & $0.145 \pm 0.009 \mathrm{a}$ & $1.036 \pm 0.023 \mathrm{a}$ \\
\hline
\end{tabular}

Value are means \pm standard errors. Means with the same letter within each column are not significantly different at $p<$ 0.05 .

\subsection{Effect of salt stress on photosynthetic characteristics of $S$. nigrum}

With the aggravation of salt stress, Pn, Gs and $\mathrm{Ci}$ of $S$. nigrum leaves gradually decreased, and the differences were significant among treatments. When the concentration of $\mathrm{NaCl}$ was $300 \mathrm{mmol} / \mathrm{L}$, the Pn, Gs and
Ci decreased by 67.16\% $(\mathrm{P}<0.05), 66.72 \%(\mathrm{P}<0.05)$ and $39.34 \%(\mathrm{P}<0.05)$ respectively. Compared with the control, the treatment of salt stress significantly reduced the $\mathrm{Tr}$ of leaves, among which $200 \mathrm{mmol} / \mathrm{L} \mathrm{NaCl}$ solution decreased the most significantly, which was $28.95 \%$ lower than the control $(\mathrm{P}<0.05)$.

Table 2. Photosynthetic characteristics of S. nigrum.

\begin{tabular}{ccccc}
\hline $\begin{array}{c}\mathrm{NaCl} \\
(\mathrm{mmol} / \mathrm{L})\end{array}$ & $\begin{array}{c}\mathrm{Pn} \\
\left(\mu \mathrm{mol} \mathrm{CO} / \mathrm{m}^{2} / \mathrm{s}\right)\end{array}$ & $\begin{array}{c}\mathrm{Gs} \\
\left(\mathrm{mol} \mathrm{H}_{2} \mathrm{O} / \mathrm{m}^{2} / \mathrm{s}\right)\end{array}$ & $\begin{array}{c}\mathrm{Ci} \\
(\mu \mathrm{mol} \mathrm{CO} / \mathrm{mol})\end{array}$ & $\begin{array}{c}\mathrm{Tr} \\
\left(\mathrm{mmol} \mathrm{H}_{2} \mathrm{O} / \mathrm{m}^{2} / \mathrm{s}\right)\end{array}$ \\
\hline 0 & $9.125 \pm 0.252 \mathrm{a}$ & $0.640 \pm 0.024 \mathrm{a}$ & $354.6 \pm 4.33 \mathrm{a}$ & $4.601 \pm 0.118 \mathrm{a}$ \\
100 & $6.722 \pm 0.263 \mathrm{~b}$ & $0.426 \pm 0.017 \mathrm{~b}$ & $328.5 \pm 2.69 \mathrm{~b}$ & $3.752 \pm 0.106 \mathrm{~b}$ \\
200 & $4.468 \pm 0.285 \mathrm{c}$ & $0.316 \pm 0.007 \mathrm{c}$ & $270.1 \pm 5.43 \mathrm{c}$ & $3.269 \pm 0.010 \mathrm{c}$ \\
300 & $2.997 \pm 0.082 \mathrm{~d}$ & $0.213 \pm 0.014 \mathrm{~d}$ & $215.1 \pm 6.33 \mathrm{~d}$ & $3.543 \pm 0.003 \mathrm{~b}$ \\
\hline
\end{tabular}


Value are means \pm standard errors. Means with the same letter within each column are not significantly different at $p<$ 0.05 .

\subsection{Effect of salt stress on antioxidant enzyme activity of $S$. nigrum}

With the aggravation of salt stress, the SOD activity of $S$. nigrum decreased gradually. When the concentration of $\mathrm{NaCl}$ was $300 \mathrm{mmol} / \mathrm{L}$, the SOD activity of $S$. nigrumdecreased by $53.39 \%(\mathrm{P}<0.05)$. The activities of
POD, CAT and soluble protein in S. nigrum leaves increased first and then decreased with the aggravation of salt stress. When the concentration of $\mathrm{NaCl}$ was 100 $\mathrm{mmol} / \mathrm{L}$, the activities of POD, CAT and soluble protein decreased by 50.94\% $(\mathrm{P}<0.05), 15.68 \%(\mathrm{P}<0.05)$ and $54.76 \%(\mathrm{P}<0.05)$ respectively.

Table 3. Antioxidant enzyme activity of S. nigrum.

\begin{tabular}{|c|c|c|c|c|}
\hline $\begin{array}{c}\mathrm{NaCl} \\
(\mathrm{mmol} / \mathrm{L})\end{array}$ & $\begin{array}{l}\text { SOD activity } \\
(\mathrm{U} / \mathrm{g})\end{array}$ & $\begin{array}{l}\text { POD activity } \\
\text { (U/g/min) }\end{array}$ & $\begin{array}{c}\text { CAT activity } \\
(\mathrm{mg} / \mathrm{g} / \mathrm{min})\end{array}$ & $\begin{array}{l}\text { Soluble protein } \\
\text { content } \\
(\mathrm{mg} / \mathrm{g})\end{array}$ \\
\hline 0 & $333.2 \pm 21.16 \mathrm{a}$ & $758 \pm 6.48 \mathrm{c}$ & $5.23 \pm 0.17 \mathrm{c}$ & $25.86 \pm 0.69 \mathrm{c}$ \\
\hline 100 & $233.0 \pm 8.08 b$ & $1545 \pm 49.47 \mathrm{a}$ & $6.05 \pm 0.16 \mathrm{a}$ & $40.02 \pm 1.22 \mathrm{a}$ \\
\hline 200 & $218.3 \pm 13.21 b$ & $1254 \pm 59.95 b$ & $5.71 \pm 0.16 \mathrm{ab}$ & $32.08 \pm 2.82 b$ \\
\hline 300 & $155.3 \pm 3.38 \mathrm{c}$ & $829 \pm 19.00 \mathrm{c}$ & $5.30 \pm 0.17 \mathrm{bc}$ & $29.84 \pm 1.63 b c$ \\
\hline
\end{tabular}

$\overline{\text { Value are means } \pm \text { standard errors. Means with the same letter within each column are not significantly different at } p<}$ 0.05 .

\section{Conclusions}

With the aggravation of salt stress, the contents of chlorophyll a, chlorophyll b, carotenoids and total chlorophyll in $S$. nigrum leaves showed a trend of first flattening and then increasing, while $\mathrm{Pn}$, Gs and $\mathrm{Ci}$ of leaves gradually decreased, and the differences were significant among treatments. In addition, in the aspect of antioxidant enzyme activity, the increase of $\mathrm{NaCl}$ concentration decreased the activity of SOD, while the activities of POD, CAT and soluble protein increased first and then decreased with the increase of $\mathrm{NaCl}$ concentration. Therefore, under salt stress, S. nigrum increased the content of photosynthetic pigment, improved the photosynthetic characteristics and antioxidant enzyme activity, and showed certain salt tolerance.

\section{References}

1. Jing, Y.P., Lin C.Y., Zhao P.Y., Li, X.P., Zhao, Q., Liu, Y.J., Liu, M., Tuo, D.B., Wang, L.J., Yang, X. (2020) Salinized soil improvement by planting 5 plant species in Hetao irrigation area.Soils and Crops., 9: 114-125.

2. Wang, Y.C., Wang, D.X. (2012) Effects of salt stress on chlorophyll content and net photosynthetic rate of woody saltbush.Transactions of the Chinese Society of Agricultural Engineering., 28: 151-158.

3. Yang, Y.K., Geng, J.B., Yu, Q.Q., Wang, J., Yu, W.Y., Zhao, W. (2019) Research progress of saline alkali soil utilization and improvement. Agriculture and Technology., 24: 108-111.

4. Zhang, J.F., Song, Y.M., Xing, S.J., Ma, B.Y., Xi, J.B. (2002) Saline soil amelioration and forestation techniques.Journal of Northeast Forestry University., 30: 124-129.

5. Xiong, Z.M., Wang, L.N. (2020) Response of three turfgrasses to soil salt stress. Jiangsu Agricultural Sciences., 48: 143-146

6. Wu, F.Z. (2019) Growth and physiological response and salt-tolerance differences of three blueberry seedlings under salt stress. Plant Physiology Journal., 55: 1638-1646

7. Wang, D.M., Jia, Y., Cui, J.Z. (2009) Advances in research on effects of salt stress on plant and adaptive mechanism of the plant to salinity. Chinese Agricultural Science Bulletin., 25: 124-128.

8. Song, Y.,Cui, X.H., Zhang, M., Miao C.L., Cui, S.M., Ye, L.H., (2019) Effects of salt stress on physiological characteristics and ion distribution of tomato seedlings. Journal of Northern Agriculture., 47:115-121.

9. Xu, D.H., Yu, C.Y., Han, C.H. (2007) Chemical 
constituents and pharmacological effects of Solanum nigrum. Heilongiiang Journal of Traditional Chinese Medicine., 45-47.

10. Li, H.L., Mei, Q.X., Zhang, Z.Q., Chen, Z.L., Jiang, Q.M. (2011) Research Progress on chemical constituents and pharmacological effects of Solanum nigrum. Pharmacy Today., 21: 713-715.

11. Hao, Z.B., Cang, J., Xu, Z. (2004) Plant physiology experiment. The Polytechnic University of Harbin Press, Harbin, China. 